\title{
Correction to: Recombinant expression of Barnase in Escherichia coli and its application in plasmid purifcation
}

\author{
Ram Shankar ${ }^{1 *} \mathbb{D}$, Nina Schäfer ${ }^{1}$, Marco Schmeer ${ }^{1}$, Joe Max Risse ${ }^{2}$, Karl Friehs ${ }^{2}$ and Martin Schleef $f^{1,2^{*}}$
}

\section{Correction to: Microb Cell Fact (2021) 20:171} https://doi.org/10.1186/s12934-021-01642-y

Following publication of the original article [1], the authors would like to include the second corresponding author of the article. The second corresponding author is Martin Schleef and the affiliation of the author is given below,

Dr. Martin Schleef: PlasmidFactory GmbH \& Co. KG and Fermentation Engineering, Bielefeld University, Bielefeld, Germany. The original article has been revised.

\section{Author details}

${ }^{1}$ PlasmidFactory GmbH \& Co. KG, Meisenstrasse 96, 33607 Bielefeld, Germany ${ }^{2}$ Fermentation Engineering, Bielefeld University, Universitätsstrasse 25,

33615 Bielefeld, Germany.

Published online: 27 September 2021

\section{Reference}

1. Shankar R, Schäfer N, Schmeer M, Risse JM, Friehs K, Schleef M. Recombinant expression of Barnase in Escherichia coli and its application in plasmid purifcation. Microb Cell Fact. 2021;20:171. https://doi.org/10. 1186/s12934-021-01642-y.

\section{Publisher's Note}

Springer Nature remains neutral with regard to jurisdictional claims in published maps and institutional affiliations.

*Correspondence: ram.shankar@plasmidfactory.com;

martin.schleef@uni-bielefeld.de

${ }^{1}$ PlasmidFactory GmbH \& Co. KG, Meisenstrasse 96, 33607 Bielefeld,

Full list of author information is available at the end of the article original author(s) and the source, provide a link to the Creative Commons licence, and indicate if changes were made. The images or other third party material in this article are included in the article's Creative Commons licence, unless indicated otherwise in a credit line to the material. If material is not included in the article's Creative Commons licence and your intended use is not permitted by statutory regulation or exceeds the permitted use, you will need to obtain permission directly from the copyright holder. To view a copy of this licence, visit http://creativecommons.org/licenses/by/4.0/. The Creative Commons Public Domain Dedication waiver (http://creativeco mmons.org/publicdomain/zero/1.0/) applies to the data made available in this article, unless otherwise stated in a credit line to the data. 